ISSN 1991-8631

Original Paper

http://indexmedicus.afro.who.int

\title{
Column removal of methylene blue using activated carbon derived from water spinach (Ipomoea aquatica)
}

\author{
Timi TARAWOU ${ }^{1^{*}}$, Donbebe WANKASI ${ }^{2}$ and M. Horsfall jnr ${ }^{1}$ \\ ${ }^{1}$ Department of Pure and Industrial Chemistry, University of Port Harcourt, P. M. B. 5323, Port Harcourt, \\ Nigeria.E-mail:ttarawoufgc@yahoo.com; horsfalljnr@yahoo.com \\ ${ }^{2}$ Department of Chemistry, Niger Delta University, Wilberforce Island, Bayelsa State, Nigeria. \\ E-mail:wankasi@yahoo.com \\ *Corresponding author, E-mail: ttarawoufgc@yahoo.com, Tel: +234 (0) 803-67-26-459
}

\begin{abstract}
This study investigated column and batch sorption of methylene blue from solution using activated carbon produced from water spinach. The equilibrium data of the batch sorption process was analyzed using Langmuir and Freundlich isotherm models and the monolayer sorption capacity (441 mg/g) obtained from the Langmuir plot was compared with the column sorption capacity $(456 \mathrm{mg} / \mathrm{g}$ ) obtained from the BDST model plot. The effect of three process variables (carbon bed height, initial methylene blue concentration and flow rate) on the dynamic sorption of methylene blue on carbon was studied using breakthrough curve. From the BDST model analysis it was found that; an increase in dye concentration from 200 to $300 \mathrm{mg} / \mathrm{l}$ increased the column sorption capacity $\left(\mathrm{N}_{0}\right)$ from 371 to $478 \mathrm{mg} / \mathrm{g}$ while an increase in flow rate from 2 to $6 \mathrm{ml} / \mathrm{min}$ decreased the column sorption capacity $\left(\mathrm{N}_{0}\right)$ from 456 to $253 \mathrm{mg} / \mathrm{g}$ respectively. The correlation coefficient $\left(\mathrm{R}^{2}\right)$ values obtained from the BDST model plots were generally very high with values ranging from 0.99 to 1.000 indicating the validity of the BDST model for the present system.

(C) 2010 International Formulae Group. All rights reserved.
\end{abstract}

Keywords: Activated carbon, Basic Blue-9, BDST, Column removal, Water spinach.

\section{INTRODUCTION}

The removal of dyes and organics in an economic fashion remains an important problem although a number of successive systems have been developed with adsorption techniques (Markovska et al. 2001). In the search for potential low-cost sorbents for pollutant attenuation in aqueous medium, a number of materials have been investigated for their ability for pollutant attenuation. Some of these sorbents are; fortified soil clay
(Oladoja and Asia, 2005; Oladoja and Ademoroti, 2005), tea factory waste (Cay et al. 2004; Malkoc and Nuhoglu, 2005), hydrotalcite (Lazaridis and Asouhidou, 2003), activated carbon (Han et al, 2001), cassava waste biomass (Horsfall et al, 2003), caladium bicolor (wild cocoyam) (Horsfall and Spiff, 2005).

Adsorption in columns appears to have advantage over a batch-type operation. This is because in column operation the adsorbent is 
continuously in contact with a fresh solution and consequently, the concentration in the solution in contact with a given layer of adsorbent in the column is relatively constant, whereas in batch-type operation the adsorbent effectiveness for removing solute from solution decreases as the adsorption proceeds (Emad et al. 2006). The main concern of the design of adsorption columns is the prediction of the breakthrough curve under specific conditions. The breakthrough curve represents the shape of the pollutant concentration curve as the solution leaves the bed. From the perspective of process modeling, the dynamic behaviour of a fixed bed column is described in terms of breakthrough curve (Chu, 2004). Breakthrough and bed volumes are usually employed in the evaluation of the performance of a fixed bed column (Chen and Wang, 2000). Generally, the time for breakthrough appearance and the shape of the breakthrough curve are very important characteristics for determining the operation and dynamic response of adsorption column.

Emad et al. (2006) reports that the Bed Depth Service Time (BDST) model offers the simplest approach and most rapid prediction of optimum adsorber performance design. It is a modified form of an earlier theory of Bohart and Adams in 1920. Bohart and Adams (1920) put the original basis for BDST and proposed that there is a relationship between the bed depth, D, and service time, t. The linearized form of this relationship is as expressed in equation 1 :

$$
\ln \left(\frac{C_{o}}{C_{b}}-1\right)=\ln \left(e^{K_{a} N_{o} D / F}-1\right)-K_{a} C_{o} t
$$

Where $C_{o}$ is the initial concentration of solute in liquid solution $\left(\mathrm{mg} / \mathrm{dm}^{3}\right), C_{b}$ is the concentration of solute in liquid at the breakthrough value $\left(\mathrm{mg} / \mathrm{dm}^{3}\right), K_{a}$ is the rate constant $\left(\mathrm{dm}^{3} / \mathrm{mg} \cdot \min \right), N_{o}$ is the adsorption capacity $(\mathrm{mg} / \mathrm{m}), D$ is the bed depth $(\mathrm{m}), F$ is the volumetric flow rate $\mathrm{dm}^{3} / \mathrm{min}$, and $t$ is the surface time to breakthrough ( $\mathrm{min})$. Since the exponential term $e^{K_{a} N_{o} D / F}$ is usually much greater than unity, the unity term within the brackets in the right-hand side of equation 1 is often neglected and this leads to equation 2 (Ko et al., 1999);

$$
t=\frac{N_{o} D}{C_{o} F}-\frac{1}{K_{a} C_{o}} \ln \left(\frac{C_{o}}{C_{b}}-1\right)
$$

Equation 2 enables the service time, $t$, of an adsorption bed to be determined for a specified bed depth, $D$, of the adsorbent. The second term on the right-hand side of equation 2 represents the time required for the pollutants to establish its breakthrough curve; that is, it represents that part of the bed which is not saturated when the pollutant concentration in the solution leaving the bed is above the breakthrough value of $C_{b}$. The BDST model can predict service time versus bed depth according to the desired percentage breakthrough value and can measure the capacity of the bed at various percentage breakthrough values (Ko et al., 2000). The critical bed depth, $D_{o}$, is the theoretical depth of carbon sufficient to prevent the solute concentration from exceeding value $C_{b}$ at $t=0$. By letting $t=0, Z_{o}$ is obtained from equation 1 by solving for $D$.

$D_{o}=\frac{F}{K_{a} N_{o}} \ln \left(\frac{C_{o}}{C_{b}}-1\right)$

It is important to mention that the BDST model ignores the intra-particle mass transfer resistance and the external film resistance such that the adsorbate is adsorbed onto the adsorbent surface directly. This model also considered the adsorption capacity, $N_{o}$ to be constant throughout the bed when the adsorption zone was moving at 
constant speed along the column. It was stated that this model applied well for activated carbon processes and other adsorbents (Ko et al., 2000; Walker and Weatherly, 1997).

Water spinach (Ipomoea aquatica) is a creeping, herbaceous vine that dwells in muddy stream banks, fresh water ponds and marshes. Water spinach populations have caused environmental damage by creating impenetrable masses of tangled vegetation obstructing water flow in drainage and flood control canals. They have infested lakes, ponds and river shorelines, displacing native plants that are important for fish and wildlife. The veins of the plant create dense impenetrable canopies over small ponds and retention basins creating stagnant water conditions that are ideal breeding environments for mosquitoes (Space and Imada, 2004).

Batch adsorption studies have been the conventional method of assessing the sorption capacity of low-cost, non conventional sorbents in the removal of pollutants. Batch adsorption experiments are used easily in the laboratory for the treatment of small volumes of effluents but less convenient to use on industrial scale where large volumes of waste water are continuously generated and in column sorption experiments equilibrium is not often established. The effluent concentration from fixed bed column is one of the most important parameters that are of practical importance to the column designer (Lin et al., 2004). Prediction of the outlet concentration is not easy. It usually involves solution of a set of non linear partial differential equations governing the flow and mass transfer by sophisticated numerical scheme with proper identification of many system parameters.

The objective of the current investigation was to examine the sorption of methylene blue on to activated carbon (derived from water spinach) in a downward flow packed bed column arrangement. The effects of design parameters, such as bed height, initial methylene blue concentration and flow rate have been investigated. The breakthrough profiles for the sorption of methylene blue were analyzed using bed depth service time (BDST) model.

\section{MATERIALS AND METHODS}

The fresh water weed, viz; water spinach (Ipomoea aquatica) was collected from the Epie River in Yenagoa of Bayelsa State of Nigeria. The sample collected was washed thoroughly with water and then rinsed with de-ionized water and air-dried. The airdried weed was then cut into small pieces and carbonized.

\section{Carbonization of water spinach}

The dried plant based biomaterial was carbonized according to the method described by Tarawou and Horsfall (2007).

\section{Chemical Activation of Carbon}

The activation followed the method described by Toles et al. (1997).

\section{Adsorbate}

Methylene Blue (a cationic dye) was used for the adsorption studies. Methylene blue (C. I. 52015, $\lambda_{\max }=664 \mathrm{~nm}$ ) was manufactured by Gurr, BDH Chemicals Ltd, Poole England. The molecular formula of methylene blue is $\mathrm{C}_{16} \mathrm{H}_{18} \mathrm{CIN}_{3} \mathrm{~S}$ with a molecular weight of 319.86. A stock solution of the dye with a concentration of $1000 \mathrm{mg}$ per litre was prepared. This was done by weighing $1.0 \mathrm{~g}(1000 \mathrm{mg})$ of dye and dissolving it in a $1000 \mathrm{ml}$ volumetric flask. The working solution was prepared by diluting the stock solution with deionized water to give the appropriate concentration of the working solutions. The concentration of 
the residual dye solution was measured using UV visible spectrophotometer at a wavelength corresponding to the maximum absorbance for the dye solution $\left(\lambda_{\max }=664 \mathrm{~nm}\right)$.

\section{Batch sorption studies}

In order to determine the sorption isotherm, $4.0 \mathrm{~g}$ of activated carbon of $200 \mu \mathrm{m}$ particle size was contacted with $50 \mathrm{ml}$ of dye solution of varying concentrations (50-300 $\mathrm{mg} / \mathrm{l})$. The experiment was carried out at room temperature at the agitation rate of $150 \mathrm{rpm}$ on a mechanical shaker for $4 \mathrm{hrs}$. The time of study was based on earlier time dependent experiments of this research that equilibrium could be established in $3 \mathrm{hrs} 20$ mins. The remaining concentration of dye in solution was determined using UV visible spectrophotometer.

\section{Column sorption studies}

A glass column $(30 \times 1.4 \mathrm{~cm})$ was packed with the activated carbon on a glass wool support. The fixed bed column of activated carbon was prepared by a dry packing technique (Netpradit et al., 2004). In order to yield different bed heights; 1.29, 2.97 and $4.33 \mathrm{~g}$ of activated carbon was added to the glass column to produce bed height of 3,6 and $9 \mathrm{~cm}$ respectively. The bed was flushed several times with de-ionized water to ensure a close packing of the activated carbon particles to avoid cracks, channels or void during the transit of the wastewater through the column. The bed was allowed to drain completely before the loading of the activated carbon bed with the sorbate. The dye solution was fed through the bed in a downward flow mode under gravity. The effluent from the activated carbon bed was collected at fixed volume $(50 \mathrm{ml})$ and the time of each collection noted. The loading of the carbon bed continued until the methylene blue concentration in the effluent was $90 \%$ of the influent concentration which was regarded as the exhaustion point. Experiments were carried out at varying bed height (3, 6 and 9 $\mathrm{cm})$, concentration $(200,250$ and $300 \mathrm{mg} / \mathrm{l})$ and flow rate $(2,4$ and $6 \mathrm{ml} / \mathrm{min})$.

\section{RESULTS}

\section{Characterization of carbon}

The data for proximate analyses, physical properties of the activated carbon are presented in Table 1.

\section{Sorption isotherm studies}

The equilibrium relationship between the concentration of methylene blue in solution phase and on the activated carbon was studied at room temperature. Equilibrium studies are described by a sorption isotherm characterized by certain constants whose values express the surface properties and affinity of the adsorbent. The equilibrium data obtained from this study were analyzed using two isotherm models, Langmuir and Freundlich isotherm models. The Langmuir isotherm model was chosen for the estimation of maximum adsorption capacity corresponding to complete monolayer coverage on the activated carbon surface. The linearized form of the Langmuir equation can be represented as:

$$
\frac{C_{e}}{q_{e}}=\frac{1}{q_{m} K_{L}}+\frac{C_{e}}{q_{m}}
$$

Where $\mathrm{k}_{\mathrm{L}}$ is a constant that is related to the adsorption/desorption energy, $\mathrm{q}_{e}$ is the amount of sorbate sorbed at equilibrium per unit mass of sorbent, $\mathrm{q}_{\mathrm{m}}$ is the monolayer capacity, $\mathrm{Ce}$ is the concentration of the sorbate at equilibrium. The slope and intercept of the plot of equation 4 gives the value of $\mathrm{q}_{\mathrm{m}}$ and $\mathrm{k}_{\mathrm{L}}$.

The Freundlich isotherm indicates the surface heterogeneity of the sorbent. The linearized form of the isotherm is given as: 


$$
\operatorname{In} q_{e}=\operatorname{In} K_{F}+\frac{1}{n} \operatorname{In} C_{e}
$$

Where $\mathrm{q}_{e}$ is the amount of sorbate sorbed at equilibrium per unit mass of sorbent, $\mathrm{Ce}$ is the concentration of the sorbate at equilibrium, $K_{F}$ and $\mathrm{n}$ are the Freundlich constants. The value of $\mathrm{n}$ indicates the affinity of the sorbent towards the biomass. Plots of In $\mathrm{q}_{\mathrm{e}}$ against $\ln \mathrm{C}_{\mathrm{e}}$ should give a straight line. The constants $n$ and $K_{F}$ are obtained from the slope and intercept of the straight line.

The analysis of the results using these isotherms showed that the Freundlich sorption isotherm (Figure 2) described the sorption process better than the Langmuir isotherm (Figure 1). This is based on the values of regression coefficients $\left(R^{2}\right)$ obtained. The $R^{2}$ values and the sorption isotherm parameters calculated from the slope and intercept of the plots of Figures 1 and 2 are presented in Table 4.

\section{Breakthrough curve}

In this study, the dimensionless concentration $\mathrm{C}_{\mathrm{t}} / \mathrm{C}_{\mathrm{o}}$ was plotted against volume of liquid treated at a concentration of $250 \mathrm{mg} / \mathrm{l}$ at different bed heights and is presented in Figure 3. The breakthrough point was assumed as the point where $\mathrm{C}_{\mathrm{t}} / \mathrm{C}_{\mathrm{o}}$ equals $10 \%$ of the inlet feed concentration which was $0.1 \mathrm{C}_{\mathrm{t}} / \mathrm{C}_{\mathrm{o}}$ or $25 \mathrm{mg} / \mathrm{l}$. The exhaustion point was assumed when the effluent concentration of dye from the carbon bed approached $90 \%$ (or $225 \mathrm{mg} / \mathrm{l}$ ) of the influent concentration.

\section{BDST model with variation in initial dye concentration}

The BDST model plot of service time (t) against the bed depth (D) was taken according to equation 2 and is presented in Figure 4. It was observed that a linear relationship was established between $\mathrm{t}$ and $\mathrm{D}$. This confirms equation (2). The operating characteristics of the activated carbon bed at different methylene blue concentration are presented in Table 2.

\section{BDST model with variation in flow rate}

The effect of volumetric flow rate on bed performance was described using the BDST model. In this study, the service time versus bed depth for methylene blue dye at constant concentration with breakthrough point of $10 \%$ of the inlet dye concentration $(250 \mathrm{mg} / \mathrm{l})$ was plotted and is presented in Figure 5. It was observed that a linear relationship was established between service time ( $\mathrm{t}$ ) and bed depth (D). The characteristics of the activated carbon bed at different flow rates are presented in Table 3.

Table 1: Physicochemical characteristics of activated carbon from water spinach.

\begin{tabular}{ll}
\hline Property & Activated carbon \\
\hline Moisture & $15.70 \pm 0.00$ \\
Porosity & $0.873 \pm 0.006$ \\
Iodine number & $253.58 \pm 0.21$ \\
Ash content & $27.00 \pm 0.26$ \\
Volatile matter & $38.33 \pm 0.15$ \\
Density & $0.246 \pm 0.058$ \\
pH & $8.92 \pm 0.02$ \\
Surface area $\left(\mathrm{m}^{2} / \mathrm{g}\right)$ & $100.90 \pm 1.00$ \\
\hline
\end{tabular}


Table 2: Operating characteristics of the activated carbon bed at different methylene blue concentration.

\begin{tabular}{llll}
\hline Concentration & $200 \mathrm{mg} / 1$ & $250 \mathrm{mg} / \mathrm{l}$ & $300 \mathrm{mg} / \mathrm{l}$ \\
\hline Flow rate (ml/min) & 2 & 2 & 2 \\
Linear velocity $\left(\frac{c m}{h r}\right)$ & 4.30 & 4.30 & 4.30 \\
Critical bed depth, $\mathbf{D}_{\mathbf{0}}(\mathbf{c m})$ & & & \\
& 0.25 & 0.26 & 0.87 \\
Bed sorption capacity, $\mathbf{N}_{\mathbf{o}}\left(\frac{m g}{g}\right)$ & 371 & 456 & 478 \\
BDST rate constant, $\mathbf{K}_{\mathbf{a}}\left(\mathbf{I} \mathbf{~ m g}^{-\mathbf{1}} \mathbf{h r}^{-\mathbf{1}}\right)$ & 0.041 & & \\
$\mathbf{R}^{\mathbf{2}}$ & 0.9994 & 0.040 & 0.009 \\
\hline
\end{tabular}

Table 3: Operating characteristics of the activated carbon bed at different flow rates.

\begin{tabular}{llcc}
\hline Flow rate & $2 \mathrm{ml} / 1$ & $4 \mathrm{ml} / 1$ & $6 \mathrm{ml} / 1$ \\
\hline Linear velocity $\left(\frac{c m}{h r}\right)$ & 4.30 & 8.59 & 12.89 \\
Critical bed depth, $\mathbf{D}_{\mathbf{0}}(\mathbf{c m})$ & & & \\
Bed sorption capacity, $\mathbf{N}_{\mathbf{o}}\left(\frac{m g}{g}\right)$ & 456 & 342 & 253 \\
& & & \\
BDST rate constant, $\mathbf{K}_{\mathbf{a}}\left(\mathbf{I ~ m g}^{-\mathbf{1}} \mathbf{h r}^{-\mathbf{1}}\right)$ & 7.802 & 2.045 & 3.449 \\
$\mathbf{R}^{2}$ & 0.9996 & 0.9944 & 0.9985 \\
\hline
\end{tabular}

Table 4: Comparison of equilibrium sorption capacity with bed capacity in the sorption of methylene blue on activated carbon.

\begin{tabular}{ccccccc}
\hline \multicolumn{2}{l}{ Langmuir isotherm parameters } & \multicolumn{2}{c}{ Freundlich isotherm parameters } & \multicolumn{2}{c}{ Bed capacity } \\
\hline $\mathbf{q}_{\mathbf{m}}$ & $\mathbf{K}_{\mathbf{L}}$ & $\mathbf{R}^{\mathbf{2}}$ & $\mathbf{K}_{\mathbf{F}}$ & $\mathbf{n}$ & $\mathbf{R}^{\mathbf{2}}$ & $\mathbf{N}_{\mathbf{o}}(\mathbf{m g} / \mathbf{g})$ \\
441 & 0.029 & 0.961 & 32 & 1.94 & 0.988 & 456 \\
\hline
\end{tabular}




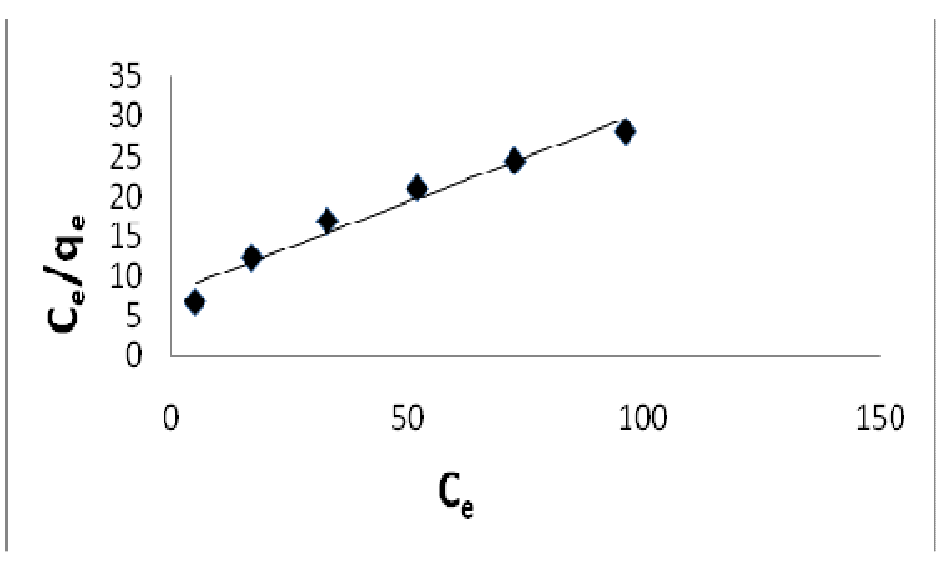

Figure 1: Langmuir isotherm plot of sorption of methylene blue on activated carbon.

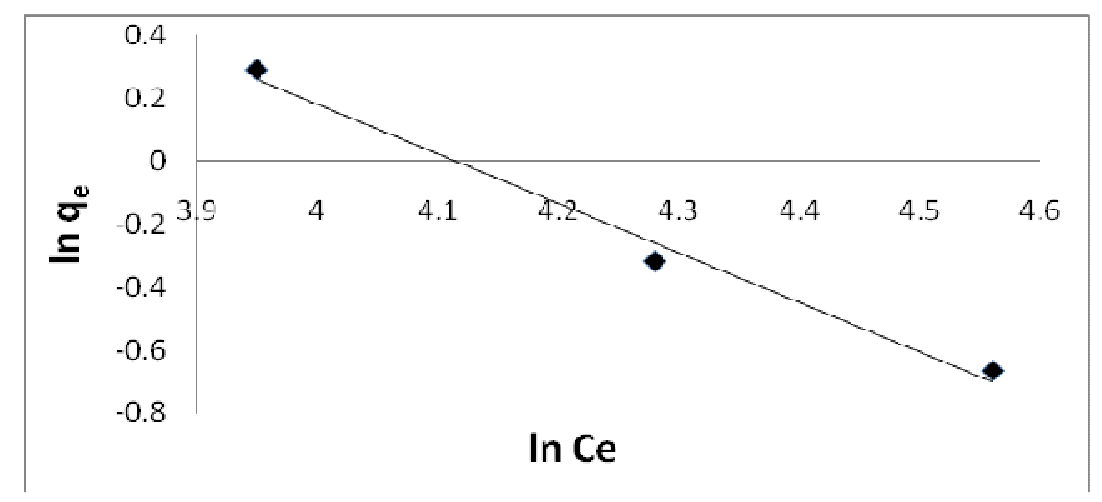

Figure 2: Freundlich isotherm plot of sorption of methylene blue on activated carbon.

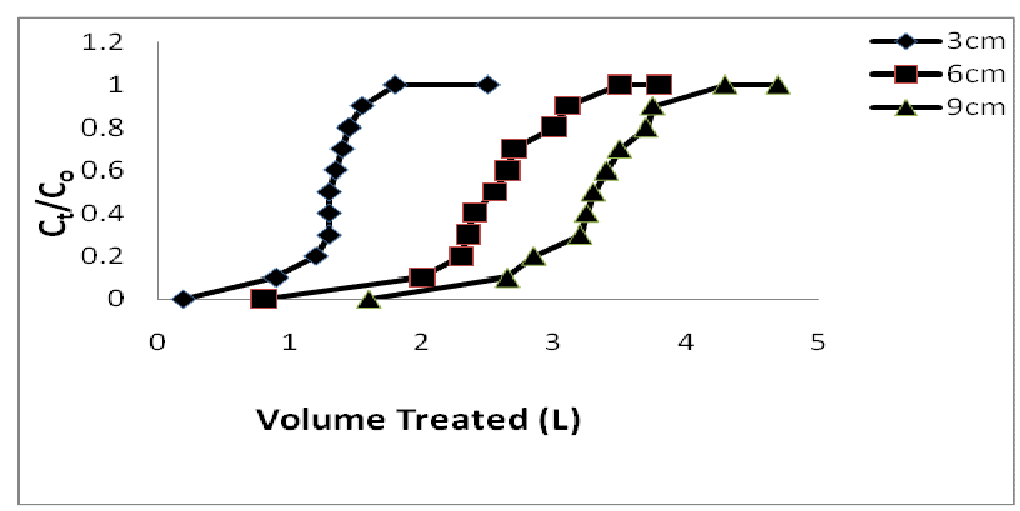

Figure 3: Effect of carbon bed height on the sorption of methylene blue on carbon fixed bed. 


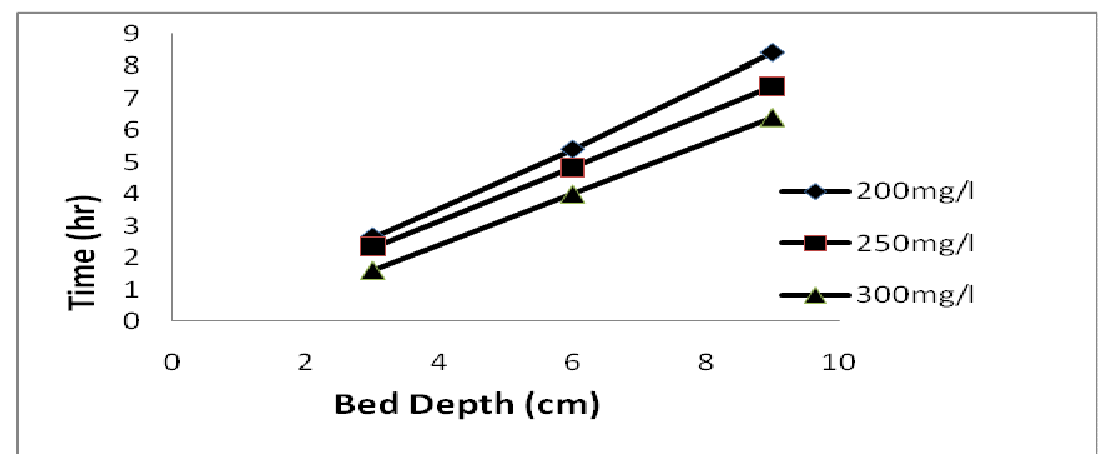

Figure 4: BDST model plots for various dye concentrations on the sorption of methylene blue on carbon fixed bed.

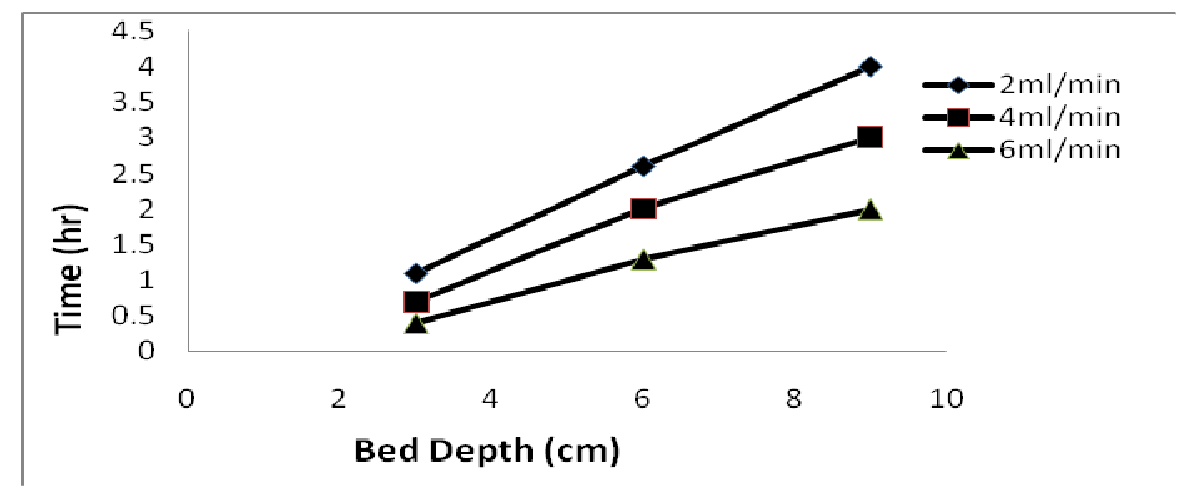

Figure 5: BDST model plots at various flow rates on the sorption of methylene blue on carbon fixed bed.

\section{DISCUSSION}

The analyses (Table 1) showed a low amount of moisture, ash and volatile matter, indicating that the particle density is relatively small and that the carbon should be an excellent material for use in column or fixed bed reactors. The porosity, iodine number, surface area and $\mathrm{pH}$ are comparable to other materials used for batch analysis (Tarawou et al., 2007; Horsfall et al., 2003).

The results in Figure 3 showed that removal of solute from solution was complete over the initial stages of operation and at this stage, the activated carbon was unsaturated and the actual effluent concentration was lower than the breakthrough concentration $\left(C_{b}\right)$. The volume of dye solution treated to achieve exhaustion concentration was lowest (1.35 1) for the column with the least bed height of $3 \mathrm{~cm}$. The volume of wastewater treated per unit weight of sorbent increased when the bed height was increased. Under gravity flow the adsorption zone moves down the column length until the upper edge of the zone gets to the bottom of the bed, then an increase in the concentration of the effluent is noticed. The breakthrough volumes obtained for the three different bed heights showed that the rate of movement of the adsorption zone was rapid when a smaller bed height was used. When the bed height was increased the movement of the adsorption zone became reduced. The volume of wastewater treated per unit mass of carbon at exhaustion point 
was greater $(3.95$ l) for the highest bed height $(9 \mathrm{~cm})$ than the volumes obtained $(1.35$ and 2.80 1) for the other bed heights ( 3 and $6 \mathrm{~cm}$ respectively). Breakthrough time (2.33, 4.83 and $7.40 \mathrm{hrs}$ ) was found to increase with increasing bed height $(3,6$ and $9 \mathrm{~cm}$ respectively).

Table 2 reveals that variation in the initial dye concentration also affected the BDST constants, with some trends being established. It was observed that, an increase in dye concentration increased the critical bed depth $\left(D_{0}\right)$ of the adsorption column. An increase in dye concentration also increased the column adsorption capacity $\left(\mathrm{N}_{\mathrm{o}}\right)$ using the BDST model. The increase in sorption capacity with increase in concentration may be due to the fact that, by increasing the dye concentration, the driving force increases and the rate of dye uptake by the adsorbent particles also increased. The observed increase in service time at lower concentration may be due to the fact that, by increasing the dye concentration, the driving force increases which enhance the rate of dye diffusion within the adsorbent particles and saturates the binding sites more quickly. Similar trends were observed by Walker and Weatherly (1997), Kumer et al. (2005) and Emad et al. (2006). The high correlation coefficient $\left(\mathrm{R}^{2}\right)$ values indicate the validity of BDST model for the present system.

Figure 5 shows that the breakthrough time decreased with increase in flow rate. It was also observed that the slope of the BDST plots decreased with increase in flow rate and beds operated at low linear flow rate produced much higher service times. The increase in critical bed depth with increase in flow rate as shown in Table 2 was not unexpected because the adsorption zone must be increased to remove the methylene blue dye under the higher flow rate. It was also observed that, the adsorption capacity $\left(\mathrm{N}_{\mathrm{o}}\right)$ in general shows a decrease with increasing flow rate. The probable reason for this observation may be that when the residence time of the solute (dye) in the column is not long enough for adsorption equilibrium to be reached at that flow rate, the dye solution leaves the column before equilibrium occurs. Thus, the contact time of dye with the activated carbon is very short at higher flow rate, causing a reduction in removal efficiency. A similar trend was observed by Vijayaraghavan and Prabu (2006). The rate constant $\left(\mathrm{K}_{\mathrm{a}}\right)$ did not show consistent trends for variation in flow rate in this system. The correlation coefficient $\left(\mathrm{R}^{2}\right)$ values obtained from the experimental data of this study were generally very high, with values all above 0.99 indicating the validity of BDST model for the present study.

The sorption capacity of the activated carbon obtained from the batch sorption studies was compared with the activated carbon bed sorption capacity $\left(\mathrm{N}_{\mathrm{o}}\right)$ of the column studies. It was found that the carbon bed sorption capacity $(456 \mathrm{mg} / \mathrm{g})$ was higher than the equilibrium sorption capacity (441 $\mathrm{mg} / \mathrm{g}$ ) obtained from the batch sorption studies. Similar results have been reported (Gupta et al., 2000). The higher capacity of column operation may be due to the continuously increasing concentration gradient at the interface of the adsorption zone as it passes through the column while the concentration gradient decreases with time in batch experiments (Gupta et al., 2000).

\section{Conclusion}

This study demonstrated that water spinach could be used as novel raw material for the production of effective activated carbon for the removal of methylene blue dye from aqueous solution. The bed volume at both the breakthrough point and exhaustion point increased with increase in bed height of the carbon. The increase in flow rate resulted in decreased methylene blue uptake, probably due to insufficient residence time of the dye in the column. The BDST model was suitable for describing the experimental data generated in 
the present study with very high correlation coefficient $\left(\mathrm{R}^{2}\right)$ values. The critical bed depth $\left(D_{0}\right)$ and the column sorption capacity $\left(\mathrm{N}_{0}\right)$ were found to increase with an increase in initial dye concentration. While the critical bed depth increases with increasing flow rate, sorption capacity was found to decrease with increase in flow rate.

\section{ACKNOWLEDGEMENTS}

This research was conducted as a part of Ph.D dissertation in the Department of Pure and Industrial Chemistry in the University of PortHarcourt. The authors would like to thank Mr. Nnamdi Tamunotroko Peter of the Postgraduate Chemistry Laboratory the University of PortHarcourt, Nigeria, for his technical assistance and the use of facilities in his Laboratory.

\section{REFERENCES}

Bohart GS, Adams EQ. 1920. Some aspects of the behaviour of charcoal with respect to chlorine. J. Am. Chem. Soc., 43: 523-529.

Cay S, Uyank A, Ozasik A. 2004. Single and binary component adsorption of copper(11) and cadmium(11) from aqueous solutions using tea-industry waste. Sep. Pur. Technol., 38: 273-280.

Chen PJ, Wang X. 2000. Removing Cu, Zn and $\mathrm{Pb}$ ion by granular activated carbon in pretreated fixed bed columns. Sep. Pur. Technol., 19: 157-167.

Chu KH. 2004. Improved fixed bed models for metal biosorption. Chem. Eng. J., 97: 233-239.

Emad NE, Stephen JA, Gavin MW. 2006. Adsorption of basic dyes onto activated carbon using micro columns. Ind. Eng. Chem. Res., 45: 6044-6049.

Gupta VK, Srivastava SK, Renu T. 2000. Design parameters for the treatment of phenolics wastes by carbon columns (obtained from fertilizer waste material). Wat. Res., 34: 1543-1550.
Han I, Schlautman MA, Batchelor B. 2001. Removal of hexavalent chromium from ground water by granular activated carbon. Wat. Environ. Res., 72: 29-38.

Horsfall M jnr, Abia A, Spiff I. 2003. A removal of $\mathrm{Cu}^{2+}$ and $\mathrm{Zn}^{2+}$ ions from wastewater by cassava (Manihot esculenta cranz) waste biomass. African $J$. Biotechnol., 2: 969-976.

Horsfall M jnr, Spiff I. 2005. Effect of metal ion concentration on the biosorption of $\mathrm{Pd}^{2+}$ and $\mathrm{Cd}^{2+}$ by caladium bicolor (wild cocoyam). African J. Biotechnol., 4: 191196.

Ko DK, Porter FJ, Mckay G. 1999. Correlation-based approach to the optimization of fixed-bed sorption units. Ind. Eng. Chem. Res., 38: 4868-4876.

Ko DK, Porter FJ, Mckay G. 2000. Optimized correlations for the fixed-bed adsorption of metal ions on bone char. Chem. Eng. Sci., 55: 5819-5828.

Kumar PG, Miranda LR, Velan M. 2005. Adsorption of bismark brown dye on activated carbon prepared from rubberwood sawdust (Hevea brasiliensis) using different activation methods. J. Hazard. Mater., B126: 63-70.

Lin SH, Juang RS, Wang YH. 2004. Adsorption of acid dye from water onto pristine and acid-activated clays in fixed beds. J. Hazard Mater., B113: 195-200.

Lazaridis NK, Asouhidou DD. 2003. Kinetics of soptive removal of chromium (VI) from aqueous solution by calcined $\mathrm{Mg}-\mathrm{AlCO}_{3}$ hydrotaleite. Wat. Res., 37: 2875-2882.

Markovska L, Meshko V, Noveski V. 2001. Adsorption of basic dyes in a fixed bed column. Korean J. Chem. Eng., 18: 190195.

Netpradit S, Thiravetyan P, Towprayoon S. 2004. Evaluation of metal hydroxide sludge for reactive dye adsorption in a fixed-bed column system. Wat. Res., 38: 71-78.

Oladoja NA, Asia IO. 2005. Studies on the use of fortified soil-clay in industrial 
wastewater treatment. Wat. Qual. Res. J. Canada., 40: 500-509.

Oladoja NA, Ademoroti CA. 2005. The use of fortified soil-clay as on site system for domestic wastewater purification. Wat. Res., 40: 613-620.

Space JC, Imada CT. 2004. Report to the Republic of Kiribati on Invasive Plant Species on the Islands of Tarawa, Abemama, Butarctari and Macana. Cont. No 2003-005 to the Pac. Biol. Surv. USDA Forest Service and Bishop Museum, Honolulu.

Tarawou T, Horsfall M jnr. 2007. Adsorption of methylene blue dye on pure and carbonized water weeds. Bioremed. J., 11: 1-8

Tarawou T, Horsfall M jnr, Jose LV. 2007. Adsorption of methyl red dye using water hyacinth (Eichornia crassipes). Biomass
Journal of Chemistry and Biodiversity, 4: 2236-2245.

Toles CA, Marshall WE, Johns MM. 1997. Granular activated carbons from nutshells for the uptake of metals and organic compounds. Carbon, 35: 1407-1414.

Vijayaraghavan K, Prabu D. 2006. Potential of Sargassum wightii biomass for copper (II) removal from aqueous solutions: Application of different mathematical models to batch and continuous biosorption data. J. Hazard. Mater., B137: 558-564.

Walker GM, Weatherley LR. 1997. Adsorption of acid dyes on to granular activated carbon in fixed beds. Wat. Res., 31: 2093-2101. 